\title{
Vegetative rescue of Cedrela fissilis Vell. by the rooting of cuttings from epicormic and canopy sprouts
}

\section{Cezário Ferreira dos Santos Junior ${ }^{*}$ (i) Tássio Dresch Rech ${ }^{2}$ (i) Marcio Carlos Navroski ${ }^{3}$ Pedro Boff ${ }^{2}$ (D) Mari Inês Carissimi Boff $^{3}$ (D)}

'Programa de Pós-graduação em Produção Vegetal, Universidade do Estado de Santa Catarina (UDESC), 88520-000, Lages, SC, Brasil. E-mail: agrosantos01@gmail.com. *Corresponding author.

${ }^{2}$ Empresa de Pesquisa Agropecuária e Extensão Rural de Santa Catarina (EPAGRI), Lages, SC, Brasil.

${ }^{3}$ Universidade do Estado de Santa Catarina (UDESC), Lages, SC, Brasil.

ABSTRACT: Cedrela fissilis is a species of great genetic diversity, with low population density and seminal propagation, which causes difficulties in the vegetative propagation process. This research evaluated the vegetative rescue and propagation of stem cutting rooting originated from epicormic and canopy sprouts of C. fissilis. For this, the induction of epicormic sprouts was evaluated 52 days after the complete girdling and semi-girdling 20 and $40 \mathrm{~cm}$ from the ground, and no girdling treatment, during spring (2018), summer (2018) and autumn (2019). The variables evaluated were, survival (\%), sprouting (\%), number, length (cm) and diameter (mm) of sprouts. The cuttings were made from spring epicormic sprouts, divided in two categories: $10 \mathrm{~cm}$ cuttings placed vertically in pits and $5 \mathrm{~cm}$ cuttings placed horizontally in furrows. The canopy sprouts were collected in the summer, then cut in apical and intermediate cuttings $(15 \mathrm{~cm})$. After 60 days, the cuttings were evaluated in survival (\%), rooting (\%), callus (\%), average number and length of roots (cm). Results showed that only the complete girdling produced sprouts (average $>67 \%$ ) with no difference between 20 and $40 \mathrm{~cm}$ heights, with a greater number of sprouts during spring. The cuttings from epicormic sprouts, planted vertically in pits presented higher percentage of rooting (44\%) than cuttings planted horizontally in furrows (17\%). Cuttings from the canopy had inconsiderable rooting (apical - 2\%; intermediate - $0 \%$ ). The girdling periods influences the number of epicormic sprouts and its use for cutting was more efficient in rooting.

Key words: Pink cedar, cloning, seasons of the year, types of cutting, rejuvenation.

Resgate vegetativo de Cedrela fissilis Vell. por enraizamento de estacas de brotos epicórmicos e de copa

RESUMO: Cedrela fissilis é uma espécie de grande diversidade genética, com baixa densidade populacional florestal, de propagação seminal, que apresenta dificuldade de ser propagada vegetativamente. O objetivo deste trabalho foi avaliar o regate e propagação vegetativa a partir do enraizamento de estacas de origem epicórmicas e de copa de C. fissilis. Para isso, a brotação epicórmica foi avaliada 52 dias após o anelamento completo e semianelamento nas alturas de 20 e $40 \mathrm{~cm}$, e tratamento sem anelamento, durante primavera (2018), verão (2018) e outono (2019). Foram avaliados: sobrevivência das árvores (\%), brotação (\%), número, comprimento (cm) e diâmetro (mm) de brotos. A estaquia utilizou brotos epicórmicos de primavera, divididos em duas categorias: estacas com $10 \mathrm{~cm}$ colocadas verticalmente em covas e estacas de $5 \mathrm{~cm}$ colocadas horizontalmente em sulcos. Brotos de copa foram coletados no verão, cortados em estacas apicais e intermediárias $(15 \mathrm{~cm})$. Após 60 dias avaliou-se das estacas: sobrevivência (\%), enraizamento (\%), calos (\%), número médio e comprimento de raizes (cm). Os resultados apresentam que apenas o anelamento completo formou brotos (média $>67 \%$ ), sem diferença entre a altura 20 e $40 \mathrm{~cm}$, com maior número de brotos durante a primavera. As estacas de brotos epicórmicos, plantadas verticalmente em covas, apresentaram a maior porcentagem de enraizamento (44\%) que estacas plantadas horizontalmente em sulcos (17\%). Estacas de copa obtiveram enraizamento desconsiderável (apicais - 2\%; intermediárias - 0\%). As épocas de anelamento influenciam no número de brotos epicórmicos e seu uso como estacas foi mais eficiente no enraizamento.

Palavras-chave: Cedro-rosa, clonagem, época do ano, tipos de estaca, rejuvenescimento.

\section{INTRODUCTION}

The pink cedar (Cedrela fissilis Vell.), Meliaceae botanical family, is a tree species of great importance to the national and international logging industry, occurring in the Amazon and Atlantic Forest biomes of Brazil (MARTINS \& LAGO, 2008). Irrational extractivism has threatened the pink cedar population, causing it to enter the list of endangered species in Brazil (BRASIL, 2014). The species 
is hermaphrodite, has predominantly allogamous reproduction and great genetic diversity with the possibility of selection of superior tree genotypes (KAGEYAMA et al., 2003).

The vulnerability of this species is aggravated due to its natural multiplicationdistribution pattern, which has showed its occurrence on isolated individuals, besides the low population density in the remnant forests and the illegal extraction of specimens (GASPER et al., 2017). Ex situ multiplication from seeds can compensate for the threat of extinction (PEREIRA et al., 2017a). However, this propagation method has the risk of indefinite genetic origin, given the cross-pollination, restricting it to a small number of parental specimens and seasonality of seeds (GANDARA et. al., 2014).

Vegetative propagation can accelerate the rescue process of the vulnerable forest species from the naturally occurring habitat changes, since parental mapping may occur alongside genetic improvement and allow for propagation material throughout the year (DIAS et al., 2015; SÁ et al., 2018; GUIMARÃES et al., 2019). Therefore, vegetative propagation presents itself as an alternative to the seminal propagation weaknesses, enabling the rescue and multiplication of superior genotypes of trees (NAVROSKI et al., 2015).

Cuttings of woody tissue of $C$. fissilis have low rooting rate, which it makes it a hard task to rescue genetic material from trees by vegetative propagation. Alternatively, the use of cuttings from young plants has been advised due to its higher vigor and cell differentiation capability (XAVIER et al., 2003a; XAVIER et al., 2003b). However, this method depends on plants originating from seeds, making it very difficult to rescue and maintain genetically superior mother trees.

The rescue and vegetative propagation of forest species has shown promising results with the induction of epicormic shoots in native species such as Ilex paraguariensis St. Hil. (NASCIMENTO et al., 2018), Anadenanthera macrocarpa (Benth.) Brenan. (DIAS et al., 2015), Araucaria angustifolia Bertol. (WENDLING et al., 2009), Eremanthus erythropappus (DC.) Macleish. (MELO et al., 2012) also in exotic species implanted in Brazil, such as Sequoia sempervirens D. Don (PEREIRA et al., 2017b), Tectona grandis L. f. (BADILLA et al., 2016), Eucalyptus cloeziana F. Muell. (ALMEIDA et al., 2007) and Toona ciliata var. australis M. Roem. (PEREIRA et al., 2015).

The difficulty of rooting woody cuttings of some tree species is related to the ontogenetic age of the material used, and can be changed through the use of cuttings from rejuvenated sprouts that have greater rooting capacity (STUEPP et al., 2015). The change of ontogenetic age in plant material is possible through cellular reprogramming causing rejuvenation which includes methods such as micropropagation of plant tissues, induction of epicormic sprouts, juvenile shoots of adult plants, seedlings and graft propagation (STUEPP et al., 2018; ZHANG et al., 2020). Among the epicormic sprouts induction techniques, complete girdling, semi-girdling and tree stem cuts are used (DIAS et al., 2015; NASCIMENTO et al., 2018; PEREIRA et al. 2015). However, there are still few vegetative rescue reports for some native Brazilian species using these techniques (STUEPP et al., 2018).

Therefore, the objective of this research was to evaluate the induction of epicormic sprouts of adult trees using the techniques of complete and semi-girdling, as well as the possibility of rooting stem cuttings of epicormic and canopy sprouts in the vegetative rescue and propagation of Cedrela fissilis.

\section{MATERIALS AND METHODS}

The study was carried out at the Biotechnology Laboratory of the Experimental Station of the Santa Catarina Agricultural Research and Rural Extension Service - EPAGRI, in Lages, Santa Catarina state, Brazil. The climate is considered $C f b$ by the Köeppen classification with an altitude of approximately 900 meters.

\section{Rooting of stem cuttings from epicormic sprouts}

The induction of epicormic sprouts was performed in three different seasons: spring (2018), summer (2018) and autumn (2019). Field treatments consisted in the lack of girdling (control); complete girdling at $20 \mathrm{~cm}$ from ground level; complete girdling at $40 \mathrm{~cm}$ from ground level; semi-girdling at $20 \mathrm{~cm}$ from ground level, and semi-girdling at $40 \mathrm{~cm}$ from ground level. The complete girdling consisted of the total removal of a bark ring and the semigirdling the removal of $50 \%$ of a bark ring with a simple pocketknife. Approximately $1 \mathrm{~cm}$ of bark was removed without damaging the intern wood.

During spring (October 2018), C. fissilis trees between three and five years old were selected in the agroforestry of EPAGRI, between 1.10 to 2.50 $\mathrm{m}$ height and $60 \mathrm{~mm} \pm 15.5 \mathrm{~mm}$ diameter. During summer (December 2018) and autumn (March 2019), trees were selected in the five-year-old planting in the Experimental field of UDESC-CAV $\left(27^{\circ} 45^{\prime} 33.50^{\prime \prime} \mathrm{S}\right.$ and $50^{\circ} 04^{\prime} 55.10^{\prime \prime} \mathrm{W}$ ), with 1.30 to $2.70 \mathrm{~m}$ height and of $67.5 \mathrm{~mm} \pm 2.1 \mathrm{~mm}$ diameter. 
The spring, summer and autumn experiments were conducted in completely randomized blocks design with six replications. Each replication composed of a tree. 52 days after installation, the experiments were evaluated regarding: survival of the girdled trees (\%), sprouting $(\%)$, average sprout number, length $(\mathrm{cm})$ and diameter $(\mathrm{mm})$ formed above and below the girdling line. Considering only epicormic sprouts above $1 \mathrm{~cm}$.

Epicormic sprouts were collected during spring 2018 and prepared into cuttings. Those were divided in two conditions: cuttings of $10 \mathrm{~cm}$ length placed vertically in pits with an average diameter of $5.91 \mathrm{~mm} \pm 1.03 \mathrm{~mm}$ maintaining two leaves, and; cuttings of $5 \mathrm{~cm}$ length placed horizontally in furrows with average diameter of $8.15 \mathrm{~mm} \pm 2.03 \mathrm{~mm}$ with one leaf above ground.

All cuttings were kept in $25 \mathrm{~L}$ plastic trays, filled with $12 \mathrm{~L}$ of expanded vermiculite and carbonized rice husk in a 1:1 volume ratio. The trays were kept in a greenhouse under controlled temperature of $25 \pm 3{ }^{\circ} \mathrm{C}$ and humidity always above $80 \%$. Plant growth regulator was not used. The experiment was conducted in completely randomized design with four replications, consisting of 12 cuttings per repetition. The cuttings were evaluated after 60 days regarding: survival $(\%)$, rooting $(\%)$, number of roots per cuttings, length of roots $(\mathrm{cm})$ and presence of callus $(\%)$

\section{Rooting of cuttings from canopy sprouts}

Canopy shoots were collected from trees over 16 years old in a secondary forest area during summer (December 2018) and taken to the laboratory where apical and intermediate cuttings were produced. The cuttings from the canopy sprouts had approximately $15 \mathrm{~cm}$ in length and between of 6.71 $\mathrm{mm} \pm 3.07 \mathrm{~mm}$ in diameter. The bases of the cuttings were cut in bevel, keeping two leaves near the upper extremity. The number of leaves were reduced aiming to avoid losing excessive water by the vegetative material. The cuttings were established in the same experimental design (completely randomized blocks) and environmental conditions of the previous test.

\section{Statistical analysis}

To achieve normality (Shapiro-Wilk) and homogeneity (Bartlett) the data were transformed by the function $\sqrt{x+1}$ and subjected to analysis of variance by the $\mathrm{F}$ test $(\mathrm{P}<0.05)$ with the aid of the InfoStat ${ }^{\mathbb{R}}$ statistical program, version 2016 (DI RIENZO et al., 2016).

\section{RESULTS AND DISCUSSION}

\section{Result of the induction of epicormic sprouts}

All trees showed survival and subsequent healing of the injured area in all girdling treatments. The control and semi-girdling treatments did not present sprout formation in any of the three evaluated periods, independent of the tree's natural environments. This indicates that the species does not have natural sprouting capacity, without a sprouting activation mechanism, such as girdling. Some species naturally sprout, as reported by PEREIRA et al. (2017b) in Sequoia sempervirens. All trees that went through the girdling rescue technique $(20 \mathrm{~cm}$ and $40 \mathrm{~cm}$ ) presented more than $67 \%$ epicormic sprouts (Table 1). The production of epicormic sprouts from complete girdling is attributed to the total cut of the phloem, which affects the auxin and cytokinin relations, photoassimilates and metabolism in the injured area (DIAS et al., 2015).

NASCIMENTO et al. (2018) observed that semi-girdling produced fewer but longer sprouts in Ilex paraguariensis in relation to complete girdling. PEREIRA et al. (2015) with the semi-girdling technique obtained new sprouts in only $55 \%$ of plants, inferior in relation to the complete girdling and cut off techniques. DIAS et al. (2015), with cut off and semigirdling, achieved $90 \%$ of new sprouts induction for Anadenanthera macrocarpa. PEREIRA et al. (2015) obtained the survival of all mother trees, with a higher number of epicormic sprouts in the cut off plants when compared to the techniques of girdling and semi-girdling in Toona ciliata var. australis.

Thus, the girdling made it possible to obtain propagation material of $C$. fissilis without causing the death of the mother tree, which is important, since it is an endangered native species (BRASIL, 2014). NASCIMENTO et al. (2018) also emphasizes the rescue using girdling techniques as the least harmful for Ilex paraguariensis mother trees present in native areas. PEREIRA et al. (2015), using the techniques of girdling, semi-girdling and cut off in Toona ciliata var. australis to promote epicormic sprouts, emphasizes the importance of the girdling technic rather than cut off due to the loss of the mother tree.

The higher average number of sprouts in girdling treatments during spring can be attributed to the higher rate of photoassimilates produced and stored during winter, which are used in the resumption of vegetative growth (TAIZ \& ZEIGER, 2009). CUSIN et al. (2017) presented that between summer and autumn apple trees displace soluble sugars to sprouts to the treetop that remained in the 
Table 1 - Survival of the girdled trees (\%), trees with sprouts (\%), average number of sprouts, average length of sprouts (cm) and average sprouts diameter ( $\mathrm{mm}$ ) of Cedrela fissilis Vell. submitted to two girdling treatments in three periods of the year.

\begin{tabular}{|c|c|c|c|c|c|}
\hline Treatments & Survival (\%) & $\begin{array}{l}\text { Sprouted } \\
\text { trees }(\%)\end{array}$ & $\begin{array}{l}\text { Sprouts number } \\
\qquad(\mathrm{cm})\end{array}$ & $\begin{array}{l}\text { Sprouts length } \\
(\mathrm{cm})\end{array}$ & $\begin{array}{l}\text { Sprouts diameter } \\
(\mathrm{mm})\end{array}$ \\
\hline \multicolumn{6}{|c|}{ 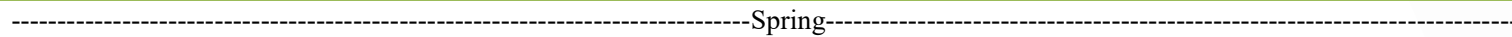 } \\
\hline Girdling $20 \mathrm{~cm}$ & $100^{\mathrm{ns}}$ & $100 \mathrm{a}$ & $6.00 \mathrm{a}$ & $12.26 \mathrm{a}$ & $4.90 \mathrm{a}$ \\
\hline Girdling $40 \mathrm{~cm}$ & 100 & $100 \mathrm{a}$ & $8.83 \mathrm{a}$ & $15.47 \mathrm{a}$ & $5.40 \mathrm{a}$ \\
\hline CV (\%) & 0.00 & 0.00 & 24.25 & 10.13 & 14.36 \\
\hline \multicolumn{6}{|c|}{ 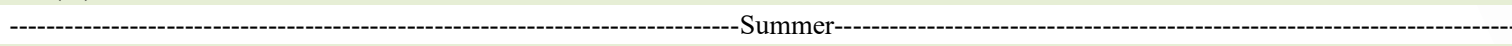 } \\
\hline Girdling $20 \mathrm{~cm}$ & $100^{\mathrm{ns}}$ & $67.00 \mathrm{a}$ & $0.83 \mathrm{a}$ & $23.67 \mathrm{a}$ & $5.89 \mathrm{a}$ \\
\hline Girdling $40 \mathrm{~cm}$ & 100 & $83.00 \mathrm{a}$ & $1.50 \mathrm{a}$ & $25.42 \mathrm{a}$ & $5.81 \mathrm{a}$ \\
\hline CV (\%) & 0.00 & 10.85 & 17.90 & 7.92 & 39.36 \\
\hline \multicolumn{6}{|c|}{ 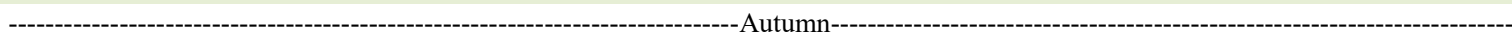 } \\
\hline Girdling $20 \mathrm{~cm}$ & $100^{\text {ns }}$ & $67.00 \mathrm{a}$ & $1.17 \mathrm{a}$ & $14.08 \mathrm{a}$ & $4.78 \mathrm{~b}$ \\
\hline Girdling $40 \mathrm{~cm}$ & 100 & $100.00 \mathrm{a}$ & $2.00 \mathrm{a}$ & $25.33 \mathrm{a}$ & $9.54 \mathrm{a}$ \\
\hline $\mathrm{CV}(\%)$ & 0.00 & 8.41 & 20.62 & 45.49 & 29.62 \\
\hline
\end{tabular}

$\mathrm{CV}$ : Coefficient of variation. $\mathrm{ns}=$ not significant. Averages followed by the same letter in the column do not differ significantly from each other by $\mathrm{F}$ test $(\mathrm{P}<0.05)$.

dormant phase, being usable in the resumption of spring. FERRIANI et al. (2011) observed that the Piptocarpha angustifolia Dusén ex Malme obtained a higher number of sprout emission during the spring period. The difference in values between inductions of epicormic sprouts suggested that this behavior can also be observed in $C$. fissilis.

The average number and length of sprouts in the girdling treatments of $20 \mathrm{~cm}$ and 40 $\mathrm{cm}$ did not differ during the three evaluation periods. Regarding the values of the average sprout diameter $(\mathrm{mm})$, the treatments between spring and summer did not present differences. The average diameter in the autumn was different for both girdles at $20 \mathrm{~cm}$ and $40 \mathrm{~cm}$ (Table 1). The difference in the autumn period between treatments may be related to climatic factors such as luminosity, caused by the shading due to the surrounding Eucalyptus benthamii trees. Physiological, nutritional and environmental conditions can interfere sprout induction, as discussed by DIAS et al. (2015).

The rescue technique and tree age affect the number of sprouts as demonstrated by BADILLA et al. (2016) with Tectona grandis. The rescue method and soil fertility can also influence sprouting in Ilex paraguariensis (NASCIMENTO et al., 2019). PEREIRA et al. (2017b) demonstrates that the rescue technique and the genetics of Sequoia sempervirens trees can influence the rooting of cuttings. The rescue technique on older $C$. fissilis trees needed to be tested to assess the influence on the production of epicormic sprouts.

Rooting results of cuttings from canopy and epicormic sprouts

The rooting percentage of apical $(2 \%)$ and intermediate $(0 \%)$ cuttings of canopy sprouts after 60 days was considerably low. It is also possible to observe a low value, with no percentage of cuttings with calluses (Table 2). The presence of roots and calluses could be attributed to a higher maturity of the cutting, which has the highest amount of lignin and lower capacity for de-differentiation of cell tissue (GUIMARÃES et al., 2019).

The cuttings placed vertically in pits from epicormic sprouts presented a higher average number of roots per cuttings $(0.71)$ than those placed horizontally in furrows $(0.35)$. The higher rate of rooting of cuttings placed vertically in pits (44\%) than horizontally in furrows $(17 \%)$ can be attributed to the rejuvenation characteristics that influence the meristematic capacity of de-differentiation and differentiation (NASCIMENTO et al., 2019). DIAS et al. (2015), observed that herbaceous cuttings of Anadenanthera macrocarpa showed a higher percentage of rooting due to its higher hormone content and low lignin concentration compared to semi-woody cuttings.

Canopy sprouts cuttings presented leaf abscission, while epicormic sprouts cuttings (vertically in pits and horizontal in furrows) maintained the 
Table 2 - Survival (\%), rooting (\%), number of roots per cuttings, length of roots $(\mathrm{cm})$ and presence of callus (\%) of canopy and epicormic sprouts of Cedrela fissilis.

\begin{tabular}{|c|c|c|c|c|c|}
\hline Types of cuttings & Survival (\%) & Rooting (\%) & Roots number & Roots length & Callus $(\%)$ \\
\hline \multicolumn{6}{|c|}{ 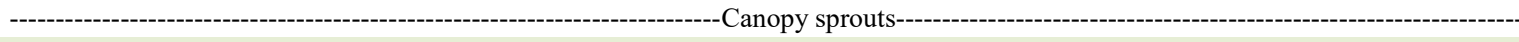 } \\
\hline Apical & $15.00 \mathrm{a}$ & $2.00 \mathrm{a}$ & $0.04 \mathrm{a}$ & $2.44 \mathrm{a}$ & $2.00 \mathrm{a}$ \\
\hline Intermediate & $17.00 \mathrm{a}$ & $0.00 \mathrm{a}$ & $0.00 \mathrm{a}$ & $0.00 \mathrm{a}$ & $0.00 \mathrm{a}$ \\
\hline $\mathrm{CV}(\%)$ & 14.27 & 4.25 & 7.49 & 22.70 & 4.21 \\
\hline \multicolumn{6}{|c|}{ - } \\
\hline Vertical in pits & $65.00 \mathrm{a}$ & $44.00 \mathrm{a}$ & $0.71 \mathrm{a}$ & $6.02 \mathrm{a}$ & $92.00 \mathrm{a}$ \\
\hline Horizontal in furrows & $65.00 \mathrm{a}$ & $17.00 \mathrm{~b}$ & $0.35 \mathrm{~b}$ & $7.77 \mathrm{a}$ & $83.00 \mathrm{a}$ \\
\hline $\mathrm{CV}(\%)$ & 15.79 & 16.32 & 27.47 & 66.96 & 10.08 \\
\hline
\end{tabular}

$\mathrm{CV}$ : Coefficient of variation. Averages followed by the same letter in the column do not differ significantly from each other by the $\mathrm{F}$ test $(\mathrm{P}<0.05)$

leaves. The leaves promote the maintenance of auxins, cofactors and photoassimilates that favor the induction of roots, as noted in Drimys brasiliensis Miers by ZEM et al. (2015). PEREIRA et al. (2015) obtained a higher percentage of rooting with cuttings with leaves in Toona ciliate var. australis, where cuttings without leaves did not root, even with IBA use. Better rooting results were observed with Cedrela fissilis leaf mini-cuttings (XAVIER et al., 2003a). Leaf abscission is caused by stress on cuttings that induce ethylene production leading to leaf fall (TAIZ \& ZEIGER, 2009).

Cuttings placed vertically in pits $(92 \%)$ and horizontal in furrows $(83 \%)$ of epicormic sprouts showed higher callus values (Table 2). This is because some forest species calluses precede the presence of roots, creating favorable conditions for cuttings survival (MENDONÇA et al., 2018). All evaluated $C$. fissilis cuttings that rooted presented calluses. NAVROSKI et al. (2015) observed the same phenomena, in which all rooted Sequoia sempervirens cuttings had calluses at the base of the cutting. In the vegetative propagation of Caryocar brasiliense Camb. with material from pruned young branches, GUIMARÃES et al. (2019) observed that rooting and callogenesis depend directly on leaf maintenance.

The formation of adventitious roots decreases with ontogenetic maturity, hindering their ability to clone vegetative material (ZHANG et al., 2020). Adventitious roots are formed by cells of nonrooting tissues such as stem and leaves, originated from cambial or meristematic cells. Their formation is controlled by phytohormones and cellular de- differentiation, in addition to epigenetics, plant nutrition and environmental stimuli (DRUEGE et al., 2019). The ability to form adventitious roots is related to hormonal concentrations and reactive oxygen substances, maintaining the phenolic compound and decreasing inhibitors (DI BATTISTA et al., 2019; STEFFENS \& RASMUSSEN, 2016). ABU-ABIED et al. (2012) demonstrated that juvenile cuttings have a higher concentration of nitric oxide than mature cuttings, due to gene express for nitrate reductase (NIA).

PIMENTEL et al. (2019) reported that rooting of mini-cuttings was influenced by genotype and collection time in mini-stumps of Ilex paraguariensis. SÁ et al. (2018) demonstrated that mini-cuttings collected in the spring period presented a higher rooting rate than winter, summer and autumn. STUEPP et al. (2015) observed that the rooting of cuttings from epicormic sprouts was influenced by the age and period of the girdling technique application and cut off from the matrices. It evidenced that cutting rejuvenation tend to have greater rooting than mature material, as shown by the present research. Studies showed that rooting of Cedrela fissilis minicuttings is related to material rejuvenation, and that growth regulator has no rooting action (XAVIER et al. 2003a; XAVIER et al., 2003b).

In Brazil, to the detriment of the diversity of Cedrela fissilis, mother trees existing among the forest remnants, the present study allows the rescue of promising genetic material through rejuvenation. This can be used for epicormic sprout cuttings, with higher rooting rates compared to more mature material. 


\section{CONCLUSION}

The semi-girdling and no girdling of tree stem of Cedrela fissilis did not induce the generation of epicormic sprouts. The complete girdling performed $20 \mathrm{~cm}$ or $40 \mathrm{~cm}$ above the ground, showed no difference between them, being more efficient in the emission of epicormic sprouts. However, the spring period presented a higher number of sprouts.

The use of cuttings from canopy sprouts is not recommended due to the low percentage of rooting. Cuttings from epicormic sprouts placed vertically in pits are more recommended because they have a higher rooting rate, being viable to vegetative propagation of Cedrela fissilis.

\section{ACKNOWLEDGEMENTS}

This research was supported by FAPESC (Rede Guarani Serra Geral, conv. FAPESC2015TR1067) and MCTI/ CNPq N $^{\circ}$ 20/2017 Nexus II - CNPq 441396/2017-8. To Programa de Bolsas de Monitoria de Pós-Graduação - PROMOP/UDESC which awarded a scholarship.

\section{DECLARATION OF CONFLICT OF INTEREST}

The authors declare no conflict of interest. The founding sponsors had no role in the design of the study; in the collection, analyses, or interpretation of data; in the writing of the manuscript, and in the decision to publish the results.

\section{AUTHORS' CONTRIBUTIONS}

The authors contributed equally to the manuscript.

\section{REFERENCES}

ALMEIDA, F. D. et al. Vegetative propagation of selected Eucalyptus cloeziana F. Muell. trees through cutting technique. Revista Árvore, v.31, n.3, p.445-453, 2007. Available from: <https://doi.org/10.1590/S0100-67622007000300010>. Accessed: Nov. 05, 2020. doi: 10.1590/S0100-67622007000300010.

ABU-ABIED, M. et al. Microarray analysis revealed upregulation of nitrate reductase in juvenile cuttings of Eucalyptus grandis, which correlated with increased nitric oxide production and adventitious root formation. Plant J., v.71, n.5, p.787-99, 2012. Available from: $<$ https://doi.org/10.1111/j.1365-313X.2012.05032.x>. Accessed: Nov. 02, 2020. doi: 10.1111/j.1365-313X.2012.05032.x.

BADILLA, Y. et al. Redemption vegetative of the Tectona grandis Linn F. trees by the stakes rooting. Nativa, v.4, n.2, p.91-96, 2016. Available from: <http://dx.doi.org/10.14583/2318-7670. v04n02a07>. Accessed: Dec. 16, 2019. doi:10.31413/nativa. v4i2.3407.

BRASIL. Ministério do Meio Ambiente. Portaria nº 444 de 17 de dezembro de 2014 - Anexo I. Lista Nacional Oficial de Espécies da Fauna Ameaçadas de Extinção. 2014. Diário Oficial da União da República Federativa do Brasil, Brasília, DF, 18 dec. 2014. Available from: <https://www.icmbio.gov.br/ portal/images/stories/biodiversidade/fauna-brasileira/portarias/ PORTARIA_N_444_DE_17_DE_DEZEMBRO_DE_2014.pdf $>$. Accessed: Oct. $12, \overline{2019}$.

CUSIN, R. et al. Determinação da conectividade xilemática em gemas dormentes de Malus $\times$ doméstica através da aplicação de corante. Revista interdisciplinar de ciências aplicada, v.2, n.4, p.29-35. 2017. Available from: <http://www.ucs.br/etc/revistas/ index.php/ricaucs/issue/view/237/showToc $>$. Accessed: Dec. 02, 2019.

DI BATTISTA, F. et al. Metabolic changes associated to the unblocking of adventitious root formation in aged, rootingrecalcitrant cuttings of Eucalyptus gunnii Hook. f. (Myrtaceae). Plant Growth Regul, v.89, n.1, p.73-82, 2019. Available from: $<$ https://doi.org/10.1007/s10725-019-00515-0>. Accessed: Nov. 02, 2020. Doi: 10.1007/s10725-019-00515-0.

DI RIENZO, J. A. et al. InfoStat versão 2016 Córdoba, Argentina: Grupo InfoStat, FCA, Universidad Nacional de Córdoba, 2016. Available from: <http://www.infostat.com.ar>. Accessed: Dec. 10, 2019.

DIAS, P. C. et al. Vegetative rescue of Anadenanthera macrocarpa trees. Cerne, v.21, n.1, p.83-89, 2015. Available from: $<$ https://doi. org/10.1590/01047760201521011381>. Accessed: May, 27, 2019. doi: $10.1590 / 01047760201521011381$.

DRUEGE, U. et al. Molecular and physiological control of adventitious rooting in cuttings: phytohormone action meets resource allocation. Annals of Botany, v.123, n.6, p.929-949, 2019. Available from: <https://doi.org/10.1093/aob/mcy234>. Accessed: Nov. 02, 2020. doi: 10.1093/aob/mcy23.

FERRIANI, A. P. et al. Sprouts production and rooting of Piptocarpha angustifolia minicuttings. Pesquisa Florestal Brasileira, v.31, n.67, p.257-264, 2011. Available from: <https:// pfb.cnpf.embrapa.br/pfb/index.php/pfb/article/view/172>. Accessed: Oct. 12, 2019. doi: 10.4336/2011.pfb.31.67.257.

GANDARA et. al. Development and characterization of microsatellite loci for Cedrela fissilis Vell (Meliaceae), an endangered tropical tree species. Silvae Genetica, v.63, n.5, p.240243, 2014. Available from: <https://doi.org/10.1515/sg-20140031>. Accessed: Dec. 07, 2019. doi: 10.1515/sg-2014-0031.

GASPER, A. L. et al. Inventário Florístico de Santa Catarina. Volume VII, Espécies arbóreas raras de Santa Catarina. Blumenau: Edifurb, 2017. 256 p.

GUIMARÃES, R. N. et al. Vegetative propagation of pequi (souari nut) by cutting. Ciência Rural, v.49, n.2: e20180579, 2019. Available from: $<$ https://doi.org/10.1590/0103-8478cr20180579>. Accessed: Apr. 01, 2019. doi: 10.1590/0103-8478cr20180579.

KAGEYAMA, P. Y. et al. Genetic diversity in tropical tree species from different successional stages determined with genetic markers. Scientia Forestalis, n.64, p.93-107, 2003. Available from: < https://www.ipef.br/publicacoes/scientia/nr64/cap08.pdf>. Accessed: Jan. 03, 2021.

MARTINS, L.; LAGO, A. A. Cedrela fissilis seed preservation: seed water content and ambient temperature. Rev. bras. sementes, 
v.30, n.1, p.161-167, 2008. Available from <http://dx.doi. org/10.1590/S0101-31222008000100020>. Accessed: Jan. 04, 2021. doi: $10.1590 / \mathrm{S} 0101-31222008000100020$.

MELO, L. A. et al. Methodology for stock plants rescue and cuttings rooting of Eremanthus erythropappus. Cerne, v.18, n.4, p.631-638, 2012. Available from: <https://doi.org/10.1590/S010477602012000400013>. Accessed: Nov. 10, 2020. doi: 10.1590/ S0104-77602012000400013.

MENDONÇA, L. P. et al. Ácido-indol-3-butirico and collection time influencing on the rotation of Odontonema strictum (Nees) O. Kuntze. Revista Brasileira de Engenharia de Biossistemas, v.12, n.2, p.176-184, 2018. Available from: <http://dx.doi.org/10.18011/ bioeng2018v12n2p176-184>. Accessed: Jul. 10, 2019. doi: 10.18011/bioeng2018v12n2p176-184.

NASCIMENTO, B. et al. Nitrogenated fertilization favors vegetative rescue and propagation of Ilex paraguariensis. Cerne, v.25, n.1, p.76-83, 2019. Available from: <https://doi.org/10.1 590/01047760201925012613>. Accessed: Oct. 24, 2019. doi: $10.1590 / 01047760201925012613$.

NASCIMENTO, B. et al. Three epicormic shoot techniques in I. paraguariensis mother trees and its cutting according to the material rejuvenation. Cerne, v.24, n.3, p.240-248, 2018. Available from: $\quad<$ https://doi.org/10.1590/01047760201824032584>. Accessed: Dec. 17, 2019. doi: 10.1590/01047760201824032584.

NAVROSKI, M. C. et al. Resgate e propagação vegetativa de Sequoia sempervirens. Floresta, v.45, n.2, p.383-392, 2015. Available from: <http://dx.doi.org/10.5380/rf.v45i2.35407>. Accessed: Dec. 20, 2019. doi: 10.5380/rf.v45i2.35407.

PEREIRA, M. O. et al. Quality of seeds and seedlings of Cedrela fissilis Vell. due to the biometry of berry and seeds in different origins. Revista de Ciências Agroveterinárias, v.16, n.4, p.376-385, 2017a. Available from: <https://doi.org/1 0.5965/223811711642017376>. Accessed: Jul. 10, 2019. doi: $10.5965 / 223811711642017376$.

PEREIRA, M. O. et al. Vegetative rescue and propagation of Australian red cedar by cuttings. Pesquisa Agropecuária Brasileira, Brasília, v.50, n.4, p.282-289, 2015. Available from: <https://doi.org/10.1590/S0100-204X2015000400003>. Accessed: Dec. 27, 2019. doi: 10.1590/S0100-204X2015000400003.

PEREIRA, M. O. et al. Vegetative rescue and rooting of cuttings of different stock plants of Sequoia sempervirens. Cerne, v.23, n.4, p.435-444, 2017b. Available from: <https://doi.org/10.15 90/01047760201723042452>. Accessed: Dec. 02, 2019. doi: $10.1590 / 01047760201723042452$.

PIMENTEL, N. et al. Productivity of mini-stumps and rooting of mini-cuttings of erva mate (Ilex paraguariensis A. St.-Hil.) clones. Ciência Florestal, v.29, n.2, p.559-570, 2019. Available from:
$<$ https://doi.org/10.5902/1980509827009>. Accessed: Dec. 5, 2019. doi: $10.5902 / 1980509827009$.

SÁ, F. P. et al. Minicutting technique of yerba mate in four seasons of the year. Ciência Florestal, v.28, v.4, p.1431-1442, 2018. Available from: <http://dx.doi.org/10.5902/1980509835051>. Accessed: Dec. 30, 2019. doi: 10.5902/1980509835051.

STUEPP, C. A. et al. Propagation of yerba mate using shoots from girdling and coppicing for two stock plants ages. Cerne, v.21, n.4, p.519-526, 2015. Available from: <https://doi.org/10 1590/01047760201521041864>. Accessed: Dec. 26, 2019. doi: $10.1590 / 01047760201521041864$.

STUEPP, C. A. et al. Vegetative propagation and application of clonal forestry in Brazilian native tree species. Pesquisa Agropecuária Brasileira, Brasília, v.53, n.9, p.985-1002, 2018. Available from: <http://dx.doi.org/10.1590/s0100204x2018000900002>. Accessed: Jul. 07, 2020. doi: 10.1590/ S0100-204X2018000900002.

STEFFENS, B.; RASMUSSEN, A. The Physiology of Adventitious Roots. Plant Physiology, v.170, n.2, p.603-617, 2016. Available from: <https://doi.org/10.1104/pp.15.01360>. Accessed: Nov. 02, 2020. doi: $10.1104 /$ pp. 15.01360 .

TAIZ, L.; ZEIGER, E. Fisiologia vegetal. 4. ed. Porto Alegre: Artmed, 2009. 848 p.

WENDLING, I. et al. Indução de brotações epicórmicas ortotrópicas para a propagação vegetativa de árvores adultas de Araucaria angustifolia. Agronomía Costarricense, v.33(2), p.309-319, 2009. Available from: <http://repositorio.ucr.ac.cr/ handle/10669/13890>. Accessed: Nov. 15, 2020

XAVIER, A. et al. Rooting of stem and leaf minicuttings in the vegetative propagation of cedro-rosa (Cedrela fissilis Vell.). Revista Árvore, v.27, n.3, p.351-356, 2003a. Available from: $<$ https://doi.org/10.1590/S0100-67622003000300011>. Accessed: Sep. 23, 2019. doi: 10.1590/S0100-67622003000300011.

XAVIER, A. et al. Vegetative propagation of cedro-rosa by minicutting. Revista Árvore, v.27, n.2, p.139-143, 2003b. Available from: <https://doi.org/10.1590/S0100-67622003000200003>. Accessed: Sep. 20, 2019. doi: 10.1590/S0100-67622003000200003.

ZEM, L. M. et al. Herbaceous and semi-hardwood stem cuttings of Drimys brasiliensis. Revista Ciência Agronômica, v.46, n.2, p.396-403, 2015. Available from: <https://doi.org/10.5935/18066690.20150019>. Accessed: Dec. 15, 2019. doi: 10.5935/18066690.20150019 .

ZHANG, Z. et al. Plant rejuvenation: from phenotypes to mechanisms. Plant Cell Rep, v.39, n.10, p.1249-1262, 2020. Available from: <https://doi.org/10.1007/s00299-020-02577-1>. Accessed: Nov. 02, 2020. doi: 10.1007/s00299-020-02577-1. 